\title{
Analysis of epidemiology, lifestyle, and psychosocial factors in patients with back pain admitted to an orthopedic emergency unit
}

\author{
Análise epidemiológica, de hábitos de vida e de fatores psicossociais de pacientes \\ com dorsolombalgia em unidade de pronto atendimento ortopédico
}

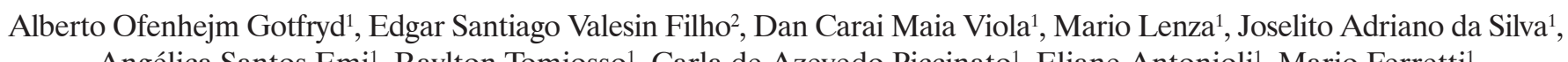
Angélica Santos Emi ${ }^{1}$, Raylton Tomiosso ${ }^{1}$, Carla de Azevedo Piccinato ${ }^{1}$, Eliane Antonioli ${ }^{1}$, Mario Ferretti ${ }^{1}$

\begin{abstract}
Objective: To correlate epidemiological data, lifestyle, and psychosocial factors as predictors for clinical manifestation of back pain in patients treated at the orthopedic emergency unit of a Brazilian tertiary care hospital, and to evaluate their interest in participating in a hypothetical program for physical rehabilitation. Methods: This is an observational cross-sectional study. We evaluated 210 patients from the emergency department of a tertiary hospital with a major complaint of back pain. We used: epidemiological multiple-choice questionnaires developed for this study; Oswestry questionnaire for physical disability; Hospital Anxiety and Depression Scale (HAD) scale. Data analyses were performed using SAS - Statistical Analysis System (SAS Institute, 2001). Measurements were performed with the SAS functions Proc MEANS and Proc Freq. Results: The mean age was 39.1 years and there was no predominance between genders. The usual work activity was administrative $(65.2 \%$ of cases). The mean body mass index was 26.0 , indicating overweight. The majority (83.3\%) of patients had low physical disability (0swestry $0-40 \%$ ). The number of medical visits in the previous 6 months $(p=0.04)$ and the scores of anxiety and depression $(p=0.05)$, independently, were correlated with physical disability. Most patients (77\%) would agree to participate in a hypothetical program of physical rehabilitation for prevention of back pain. Conclusion: Patients with back pain complaints were predominantly young adults, sedentary or hypoactive, overweight, and with recurrent complaints of symptoms. Most participants had low levels of physical disability and would accept participation in a hypothetical physical rehabilitation program for the prevention of back pain.
\end{abstract}

Keywords: Low back pain/epidemiology; Back pain/epidemiology; Emergency relief; Physical and Rehabilitation Medicine

\section{RESUMO}

Objetivo: Correlacionar dados epidemiológicos, hábitos de vida e fatores psicossociais como preditivos para manifestação clínica de dorsolombalgia em pacientes atendidos no setor de urgências ortopédicas de hospital terciário brasileiro, além de avaliar 0 interesse em participar de programa hipotético para reabilitação física. Métodos: Trata-se de estudo observacional do tipo transversal. Foram avaliados 210 pacientes provenientes do pronto atendimento de um hospital terciário, com queixa predominante de dor nas costas. Foram utilizados: questionários epidemiológicos do tipo múltipla escolha desenvolvidos para o presente estudo; questionário Oswestry para incapacidade física; e escala Hospital Anxiety and Depression Scale (HAD). As análises dos dados foram realizadas por meio do programa SAS - Statistical Analysis System (SAS Institute, 2001). Os cálculos foram realizados com as funções Proc MEANS e Proc Freq do SAS. Resultados: A média de idade foi de 39,1 anos e não houve predominância entre os gêneros. A atividade laborativa mais frequente foi a administrativa ( $65,2 \%$ dos casos). Observou-se índice de massa corporal médio de 26,0 , que indicou sobrepeso. A maioria $(83,3 \%)$ dos pacientes apresentou baixa incapacidade física (Oswestry de 0 - 40\%). 0 número de visitas nos 6 meses anteriores $(p=0,04)$ e os escores de ansiedade e depressão $(p=0,05)$, isoladamente, tiveram correlação com a incapacidade física. A maioria dos pacientes $(77 \%)$ aceitaria participar de programa hipotético de reabilitação física para prevenção de dores nas costas. Conclusão: Os pacientes com queixa de dorsolombalgia foram, predominantemente, adultos jovens, sedentários ou hipoativos, com sobrepeso e com queixas recorrentes dos sintomas. A maioria dos participantes apresentou baixa incapacidade física e aceitaria participar de programa hipotético de reabilitação física para a prevenção de dores nas costas.

Descritores: Dor lombar/epidemiologia; Dor nas costas/epidemiologia; Socorro de urgência; Medicina Física e Reabilitação

\footnotetext{
'Hospital Israelita Albert Einstein, São Paulo, SP, Brazil.

${ }^{2}$ Hospital Cristóvão da Gama, Santo André, SP, Brazil.

Corresponding author: Alberto Ofenhejm Gotfryd - Rua Apiacás, 85 - Perdizes - Zip code: 05017-020 - São Paulo, SP, Brazil - Phone: (55 11) 2151-8709 - E-mail: alberto.gotfryd@einstein.br Received on: Jan 9, 2015 - Accepted: May 27, 2015

Conflict of interest: none.

DOI: 10.1590/S1679-45082015A03320
} 


\section{INTRODUCTION}

Back pain is the most common cause of orthopedic care given in emergency departments. It is estimated that approximately $80 \%$ of the world population will experience at least once during their lifetime an episode of incapacitating back pain. ${ }^{(1)}$ The literature shows that in up to $85 \%$ of cases, the etiological diagnosis cannot be made during the acute phase, although this does not change the initial medical approach and the natural history of the disease. ${ }^{(2)}$ Risk factors for back pain vary according to the population studied, and are influenced by age, type of work activity, levels of psychological stress, and the practice of sports activities. ${ }^{(3-5)}$ In the present study, the authors evaluate the life habits and psychosocial factors of individuals with complaints of acute back pain by means of questionnaires developed for this purpose. The hypotheses tested were that patients with back pain would be sedentary, would present with symptoms of anxiety and/or depression, and would have recurring complaints of the symptoms. As far as the authors know, there are no studies described in literature or similar studies in Brazilian patients.

\section{OBJECTIVE}

To correlate epidemiological data, life habits, and psychosocial factors as predictors of clinical manifestations of back pain, in patients seen in the orthopedic emergency department of a tertiary Brazilian hospital, and to evaluate their interest in participating in a hypothetical physical rehabilitation program.

\section{METHODS}

This is a cross-sectional observational study. This research was approved by the Research Ethics Committee of the organization, under number 538.297 and CAAE: 26629114.4.0000.0071, and all the participants agreed with the information contained in the Informed Consent Form. Two hundred and ten consecutive patients from the Orthopedics Department of the Ibirapuera Advanced Unit - Hospital Israelita Albert Einstein were assessed. Data were collected between March and September 2014, by a nursing team previously trained to participate in the study. The interview occurred after the first care given, and did not interfere with it. Multiple choice epidemiological questionnaires, developed for the present study, were used with the following variables: age; engagement in, type and frequency of sports activities; type of work activity; smoking habits; use and frequency of analgesic medications for back pain; previous visits to emergency rooms due to back pain; and hypothetical interest in participating in a postural rehabilitation and spine exercise group. The body mass index (BMI) was calculated by the ratio between the patient's weight $(\mathrm{kg})$ divided by height (meters) squared.(6) The Oswestry questionnaire, ${ }^{(7)}$ version 2.05, was used, translated into and culturally adapted to Brazilian Portuguese. ${ }^{(8)}$ The questionnaire has the objective of evaluating the influence of back pain on daily activities and is composed of ten questions with six alternatives each, with results that vary from zero (no dysfunction) to 100 (maximal dysfunction). Psychological evaluation was made by means of the Hospital Anxiety and Depression Scale (HAD) ${ }^{(9)}$ using the version translated into and culturally adapted to Brazilian Portuguese. ${ }^{(10)}$ The method is composed of 14 multiple choice questions, divided into two subscales with seven points each, and has the purpose of tracking anxiety and depression symptoms. The overall score in each subscale varies from zero (best outcome) to 21 points (worst outcome), with a cutoff score between 8 and 9 points for each one.

The inclusion criteria were patients of both genders, age between 18 and 70 years, and major complaint of pain in the dorsal and/or lumbar region. The exclusion criteria were recent back trauma; acute pathological fracture; pain irradiation to lower limbs with intensity equal to or greater than that of the back pain; neurological deficit in lower limbs; active systemic neoplastic, infectious or autoimmune diseases; prior surgery in the spinal column; and patients of other nationalities (non-Brazilian) who did not master Portuguese.

\section{Statistical analysis}

Data analyses were performed by means of the SAS - Statistical Analysis System (SAS Institute, 2001). Numerical variables were described by means and standard deviations, besides minimum and maximum values for the total group. The categorical variables were described by relative frequencies. Calculations were made with the Proc MEANS and SAS Proc Freq functions. The response variable "Oswestry score for evaluation of physical incapacity" was characterized according to gender, BMI, weight, height, anxiety/depression, occupational status, use of analgesic medication, and number of medical visits motivated by back pain.

After filtering for errors and evaluation of data distribution, the response variables were classified 
as per the Oswestry score as "low" (0 - 40\%) and "high" (41 - 100\%). Additionally, the intention of rehabilitating was reclassified into merely two groups: individuals who refused (people who answered and who certainly or probably would refuse) or accepted (people who answered and who potentially or certainly would accept) rehabilitation in a hypothetical program.

The response variables were modeled by explanatory variables according to their significance in the adjusted statistical model. Thus, variables that had a significant effect in the univariate analysis $(p<0.05)$ were maintained and used in the joint statistical analysis (multivariate model). Also, variables that did not have a significant effect were reclassified as a smaller number of categories ( 2 or 3 ). These were reanalyzed and also only included in the joint model when significant.

The influence of explanatory variables in the Oswestry score (categories "low" and "high") or in interest in rehabilitation (categories "refused" and "accepted") were investigated in a multivariate logistic analysis using Proc GLM. ${ }^{(11)}$ The statistical level of significance adopted was 0.05 .

\section{RESULTS}

Of the 6,833 orthopedic cases seen during the studied period, 210 patients (3\%) met the inclusion criteria and participated in the study. Of these, 105 were males. The mean age was 39.3 years, with $40.0( \pm 11.2)$ years for males and $38.3( \pm 9.8)$ for females. The general BMI of the sample was 26.0, higher in men $27.4( \pm 3.9)$ than in women $24.6( \pm 4.5)(\mathrm{p}<0.0001)$. Oswestry score results for evaluation of physical capacity are shown on figure 1. We noted that $83.3 \%$ of patients presented with a low degree of physical incapacity (Oswestry $\leq 40 \%$ ), and only $16.7 \%$ had a high degree (Oswestry $>40 \%$ ). No difference was observed between genders as to physical incapacity.

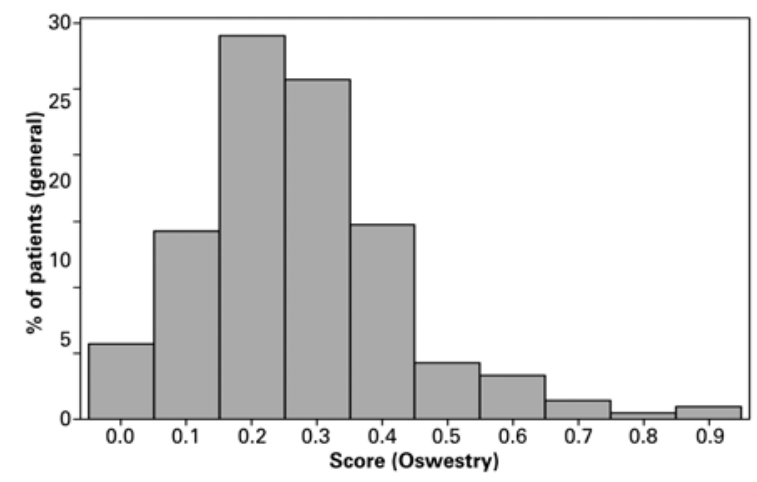

Figure 1. Frequency of patients, as per the 0swestry questionnaire
The relation between BMI and the degree of physical incapacity is shown on table 1 . We note that there was no statistically significant difference as to the BMI of patients with high or low physical incapacity $(\mathrm{p}=0.95)$. The age variable was also similar among the groups mentioned above $(p=0.61)$. Additionally, there was no difference in the mean age among male and female patients $(\mathrm{p}=0.36)($ Table 1$)$.

Table 1. Population characteristics of patients with lumbar pain, as per the Oswestry questionnaire

\begin{tabular}{|c|c|c|c|c|c|}
\hline \multirow[b]{2}{*}{ Outcome } & \multicolumn{3}{|c|}{ Incapacity (Oswestry) } & \multicolumn{2}{|c|}{ Total } \\
\hline & $\begin{array}{c}\text { Low } \\
(n=175)\end{array}$ & $\begin{array}{c}\text { High } \\
(n=35)\end{array}$ & p-value & Minimun & Maximun \\
\hline Weight, kg & $76.5(16.2)$ & $79.2(17.2)$ & 0.38 & 45 & 130 \\
\hline $\mathrm{BMl}$ & $25.9(4.4)$ & $26(4.4)$ & 0.95 & 17.7 & 41.5 \\
\hline Height, cm & $171(0.1)$ & $174(0.1)$ & 0.12 & 150 & 197 \\
\hline Age, years & $39.1(10.4)$ & $40.1(8.9)$ & 0.61 & 19 & 71 \\
\hline Female, \% & 51.4 & 42.8 & 0.36 & - & - \\
\hline
\end{tabular}

The values represent the mean or percentage of the total number of patients per group and the minimum and maximum values found. The $p$ values were obtained by linear regression for all variables and by logistic regression for the variable gender. Numerical variables are represented as mean and standard deviation. BMI: body mass index

Table 2 shows analyses of the different variables with the intensity of physical incapacity. We noted that the majority of participants $(65.2 \%)$ operated in an administrative type work activity. In this group, there was a homogeneous distribution of the participants with high and low physical incapacity $(\mathrm{p}=0.38)$.

Patients who engaged in activities that demanded great physical effort represented only $6.7 \%$ of the total sample, and in totality, presented with low physical incapacity.

The same was observed relative to sports activity $(p=0.98)$. Approximately $14 \%$ of those interviewed stated that they engaged in sports three or more times a week, while $33.3 \%$ declared that they did not participate in any sports activity. The use of medication for back pain was similar between the groups with low and high levels of incapacity $(p=0.39)$. Eighty-four percent of those interviewed did not take medications or did so sporadically.

Patients did not differ as to the number of medical visits in the previous 6 months motivated by back pain $(\mathrm{p}=0.36)$. However, when considering the frequency of medical visits, and distributing it into two groups "none" or "one and two or more visits" - we noted that patients with high physical incapacity presented with a frequency of medical visits, lower than that of patients with low incapacity ( $14.3 \%$ versus $23.4 \%$, respectively; $\mathrm{p}=0.04)$. As to smoking, there was no influence on the results of physical incapacity $(\mathrm{p}=0.26)$. Predominance 
Table 2. Distribution of patients with back pain, as per different clinical variables

\begin{tabular}{|c|c|c|c|c|}
\hline \multirow[b]{2}{*}{ Outcome } & \multicolumn{3}{|c|}{ Results (Oswestry) } & \multirow[b]{2}{*}{ p value } \\
\hline & $\begin{array}{c}0-40 \\
(n=175)\end{array}$ & $\begin{array}{l}41-100 \\
(n=35)\end{array}$ & Total & \\
\hline Occupational status ( $\%)$ & & & & 0.38 \\
\hline Does not work & 4.6 & 2.9 & 4.3 & \\
\hline Only performs activities at home & 11.4 & 8.6 & 10.9 & \\
\hline Works in an office & 62.9 & 77.1 & 65.2 & \\
\hline $\begin{array}{l}\text { Works with some type of physical } \\
\text { exertion }\end{array}$ & 13.1 & 11.4 & 12.9 & \\
\hline Works with intense physical exertion & 8 & 0 & 6.7 & \\
\hline $\begin{array}{l}\text { Sports activities } \\
\text { (last } 6 \text { months; \%) }\end{array}$ & & & & 0.98 \\
\hline None & 33.1 & 34.3 & 33.3 & \\
\hline Once a week & 10.9 & 14.3 & 11.4 & \\
\hline Twice a week & 24.6 & 22.9 & 24.3 & \\
\hline Three times a week & 16.6 & 14.3 & 16.2 & \\
\hline More than three times a week & 14.9 & 14.3 & 14.8 & \\
\hline $\begin{array}{l}\text { Use of medication for pain } \\
\text { (last six months; \%) }\end{array}$ & & & & 0.39 \\
\hline None & 40.6 & 48.6 & 41.9 & \\
\hline Sporadically & 44 & 34.3 & 42.4 & \\
\hline Monthly & 5.7 & 8.6 & 6.2 & \\
\hline Weekly & 5.1 & 0 & 4.3 & \\
\hline Daily & 4.6 & 8.6 & 5.2 & \\
\hline Medical visits (last 6 months, \%) & & & & 0.36 \\
\hline None or once, twice or more* & & & & 0.04 \\
\hline None & 54.9 & 71.4 & 57.6 & \\
\hline Once & 21.7 & 14.3 & 20.5 & \\
\hline Twice & 17.7 & 14.3 & 17.1 & \\
\hline Three times & 1.1 & 0 & 0.95 & \\
\hline Four or more times & 4.6 & 0 & 3.81 & \\
\hline Smoking (\%) & & & & 0.26 \\
\hline No & 84 & 91.4 & 85.2 & \\
\hline Yes & 16 & 8.6 & 14.8 & \\
\hline Anxiety and depression (\%) & & & & 0.05 \\
\hline No & 65.7 & 48.6 & 62.9 & \\
\hline Yes & 34.3 & 51.4 & 37.1 & \\
\hline
\end{tabular}

The values represent the mean or percentage of the total number of patients per group. The $p$-values were obtained by linear regression for all variables. *Statistical analysis was done by regrouping the number of visits into two categories: none or one visit versus two or more medical visits in the last 6 months.

was noted $(85.2 \%)$ of non-smokers among those who sought the emergency care unit. Among the patients classified as having low physical incapacity, $34.3 \%$ were characterized as anxious/depressed, while in the group with high incapacity, this value was $51.5 \%(\mathrm{p}=0.05)$ (Table 2).

Patients were questioned as to a hypothetical interest in participating in a physical rehabilitation program for the prevention of back pain, with a duration of 8 weeks, frequency of two times a week, in which each session would last 1 hour, and would be free for the participant.
Figure 2 illustrates that regardless of the degree of physical dysfunction, there was greater acceptance than refusal of the program (77\%; 161 patients).

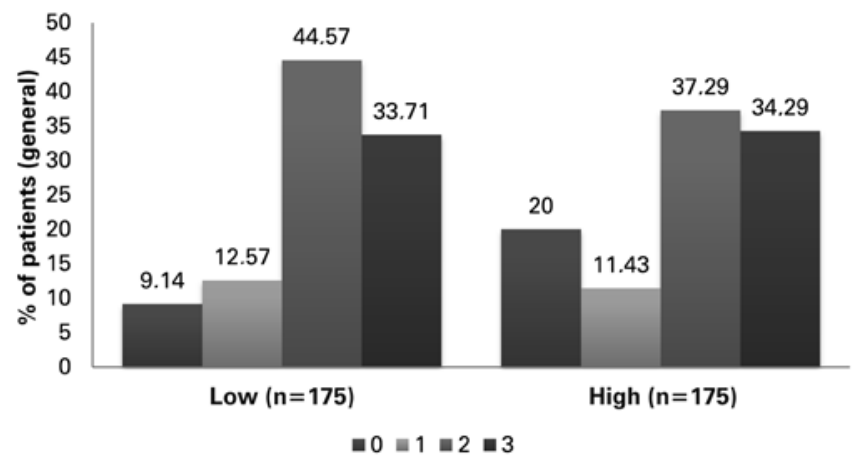

Figure 2. Interest in participating in a rehabilitation program, as per the degree of physical incapacity

Due to the predominance of individuals classified as having a low level of physical incapacity, in this group of patients the analyses of the factors that could interfere in acceptance or refusal of the rehabilitation program were concentrated. Table 3 shows that it is possible to observe that the characteristics gender, BMI, and age did not influence the acceptance or refusal of the program. On the other hand, the percentage of patients characterized as anxious/depressed was greater in the group that accepted the program, relative to the group that refused it ( $37.2 \%$ versus $23.7 \%$, respectively). Additionally, we noted that the percentage of patients that smoked was greater in the group that refused the program than in those that accepted it $(31.6 \%$ versus $11.68 \%$, respectively) (Table 3 ).

Table 3. Characteristics of patients with low physical incapacity, as per their interest in participating in a hypothetical rehabilitation program

\begin{tabular}{lcc}
\hline & \multicolumn{2}{c}{ Rehabilitation* } \\
\cline { 2 - 3 } & $\begin{array}{c}\text { Would reject } \\
(\mathbf{n = 3 8 )}\end{array}$ & $\begin{array}{c}\text { Would accept } \\
(\mathbf{n = 1 3 7 )}\end{array}$ \\
\hline Female (\%) & 52.6 & 51.1 \\
BMI & $26.8(4.6)$ & $25.7(4.3)$ \\
Age (years) & $40.6(10.6)$ & $38.8(10.1)$ \\
Anxiety/depression (\%) & 23.7 & 37.2 \\
Smoking (\%) & 31.6 & 11.68 \\
\hline
\end{tabular}

${ }^{*}$ Categories of rehabilitation: would refuse (patients who probably or certainly would not accept participating in a rehabilitation program): would accept (patients who probably or certainly would accept participation in a rehabilitation program). Numerical variables are represented as mean and standard deviation. BMI: body mass index.

Thus, we observed that among the patients with a low level of physical incapacity, those that presented 
with worse scores of anxiety and depression and that did not smoke reported greater interest in participating in a hypothetical rehabilitation program (Table 4).

Table 4. Factors that influenced patients with low physical incapacity to take an interest in participating in a hypothetical rehabilitation program

\begin{tabular}{lc}
\hline Variables & p value \\
\hline Anxiety/depression & 0.003 \\
Smoking & 0.007 \\
Smoking associated with anxiety/depression & 0.01 \\
\hline
\end{tabular}

The p-values were obtained by multivariate analysis, using logistic linear regression.

\section{DISCUSSION}

Low back pain generally affects adult patients at working age. Mehling et al. ${ }^{(12)}$ observed a mean age of 50.5 years in patients evaluated at an emergency unit. In the present study, the mean age was 39.4 years, in that, 40.0 years for women and 38.3 for men.

Additionally, age did not influence severity of physical incapacity. These data are similar to those described by Krishna et al. ${ }^{(13)}$ that observed a mean age of 41.1 years for women and 39.1 years for men, and by Serfelis et al. ${ }^{(14)}$ that observed a mean age of 39 years. According to Tulder et al. ${ }^{(15)}$ and Burton et al., ${ }^{(16)}$ the peak prevalence of low back pain occurs between 35 and 55 years of age, data similar to those observed in our sample.

Some preliminary studies demonstrated a predominance of low back pain in women, in whom chronicity is also more frequent. ${ }^{(17,18)}$ Additionally, a few factors might be related to this condition, such as psychosocial factors; greater sensitivity to nociceptors; sedentary lifestyle; greater somatization of complaints; and mood swings. In a study involving 605 patients in an emergency care unit, Mehling et al., ${ }^{(12)}$ observed a prevalence of women $(56 \%)$ over men (44\%). A similar proportion was described by Chenot et al. ${ }^{(17)}$. In the present study, there was a similar distribution among men and women, as well as among patients with low and high physical incapacity. It is believed that the reason for this is related to the similar lifestyle among men and women of the sample used in this investigation.

The correlation between lumbar pain and body weight has been the topic of various publications. ${ }^{(19-21)}$ Leboeuf et al., ${ }^{(18)}$ in a systematic literature review, suggested that body weight might be a risk factor for low back pain. In the present study, we noted a general mean BMI of 26.0, a value that indicated overweight. When genders were compared, male patients had worse results (BMI of 27.4) than the females (BMI of 24.6). However, the subgroup analysis, among patients with high or low physical incapacity, showed no influence of the BMI on this outcome.

The impact of sports activities as a method of preventing back pain is controversial. Harreby et al. ${ }^{(22)}$ accompanied 640 children until they completed 38 years of age and those who engaged in frequent physical activities presented with lower levels of lumbar pain complaints. In the present study, only $31 \%$ of patients stated that they participated in sports activities three or more times a week, a frequency considered minimal for adequate physical conditioning. ${ }^{(23)}$

The association between back pain and symptoms of anxiety and depression is described in literature. ${ }^{(24)}$ When compared to the general population, individuals with chronic lumbar pain have a three to four times greater chance of developing depression. (25) Also, individuals with depression have a high frequency of lumbar pain secondary to somatization, with a poorly known pathophysiology. ${ }^{(25)}$ In the present study, we noted that $51.4 \%$ of patients with high physical incapacity presented with anxiety and/or depression. These data are similar to those observed by Bishop et al., (26) that also noted a psychological deterioration as lumbar pain became chronic.

Among the patients evaluated, $42.4 \%$ had recurring complaints within 6 months. According to Van Tulder et al., ${ }^{(15)}$ the risk factors for development and chronicity of back pain are poorly understood. Krishna et al. ${ }^{(13)}$ observed $12.4 \%$ of lumbar pain relapse within 6 months. Other authors reported chronicity in $24 \% .^{(26)}$ In a systematic literature review, Pengel et al. ${ }^{(27)}$ observed that up to $73 \%$ of patients with acute back pain crises will have another episode within 12 months.

Hypotonicity from disuse and muscle fatigue resulting from repetitive activities promotes excessive load transfer to the spine, and consequently, pain. $^{(28,29)}$ In this way, physical rehabilitation programs may help in the prevention of low back pain. In the present study, $77 \%$ of patients demonstrated interest in participating of a hypothetical physical rehabilitation programs. Moreover, it was possible to identify that those interested in rehabilitating were more anxious and/or depressed.

The strength of this study consisted of the details of different epidemiological data and the identification of patient interest in participating in a physical rehabilitation program. This information may help in planning prevention and early intervention programs for back pain. Limitations of this study are the small sample size for population studies and the fact of having been conducted in a single tertiary center. 


\section{CONCLUSION}

Patients with complaints of back pain were predominantly young adults, sedentary or hypoactive, overweight, and with recurring complaints of symptoms. Individuals with greatest physical incapacity also had the worse scores of anxiety and depression. Most of the participants presented with low levels of physical incapacity and would agree to participate in a hypothetical physical rehabilitation program to prevent back pain.

\section{ACKNOWLEDGMENTS}

We would like to thank Dr. Eduardo Cordioli and Dr. Mauro Iervolino for their logistics support; the Orthopedics and Traumatology team, represented by Drs. Helio Minoru Samano, Walter Ricioli Jr., Cássio Trevisani, Victor Fruges Jr., Michel Kanas, Nacime Salomão B. Mansur, and Rômulo Ballarin Albino for their assistance support; and collaborators of the Ibirapuera Unit of Hospital Israelita Albert Einstein, who kindly helped collecting data.

\section{REFERENCES}

1. Heliövaara M, Impivaara 0 , Sievers K, Melkas T, Knekt P, Korpi J, et al. Lumbar disc syndrome in Finland. J Epidemiol Community Health. 1987;41(3):251-8.

2. Katz JN. Lumbar disc disorders and low-back pain: socioeconomic factors and consequences. J Bone Joint Surg Am. 2006;88 Suppl 2:21-4. Review.

3. Hoy D, Brooks P, Blyth F, Buchbinder R. The epidemiology of low back pain. Best Pract Res Clin Rheumatol. 2010;24(6):769-81. Review.

4. Gibson JN, Waddell G. Surgical interventions for lumbar disc prolapse: updated Cochrane Review. Spine (Phila Pa 1976). 2007;32(16):1735-47.

5. Steffens D, Maher CG, Ferreira ML, Hancock MJ, Glass T, Latimer J. Clinicians' views on factors that trigger a sudden onset of low back pain. Eur Spine J. 2014;23(3):512-9.

6. Lipschitz DA. Screening for nutritional status in the elderly. Prim Care. 1994; 21(1):55-67. Review.

7. Baker D, Pynsent P, Fairbank J. The Oswestry Disability Index revisited. In: Roland M, Jenner JR, editor. Back pain: new approaches to rehabilitation and education. Manchester, UK: Manchester University Press; 1989. p. 174-86.

8. Vigatto R, Alexandre NM, Correa Filho HR. Development of a Brazilian Portuguese version of the Oswestry Disability Index: cross-cultural adaptation, reliability, and validity. Spine (Phila Pa 1976). 2007;32(4):481-6.

9. Zigmond AS, Snaith RP. The Hospital Anxiety and Depression Scale. Acta Psychiatr Scand. 1983;67(6):361-70.

10. Botega NJ, Bio MR, Zomignani MA, Garcia C Jr., Pereira WA. [Mood disorders among inpatients in ambulatory and validation of the anxiety and depression scale 14 HAD]. Rev Saude Publica. 1995;29(5):355-63. Portuguese.

11. Hosmer Jr. DW, Lemeshow S, Sturdivant RX. Applied logistic regression. 3a ed. Estados Unidos: Wiley; 2013.
12. Mehling WE, Gopisetty V, Bartmess E, Acree M, Pressman A, Goldberg H, et al. The prognosis of acute low back pain in primary care in the United States: a 2-year prospective cohort study. Spine (Phila Pa 1976). 2012;37(8):678-84.

13. Krishna VK, Sharma D, Samuel G. Epidemiological study for evaluation of etiology and risk factors in patients with low back pain. Global Spine J. 2014;4:1-4.

14. Seferlis T, Németh G, Carlsson AM, Gillstrom P. Conservative treatment in patients sick-listed for acute low-back pain: a prospective randomised study with 12 months' follow-up. Eur Spine J. 1998;7(6):461-70.

15. van Tulder M, Becker A, Bekkering T, Breen A, del Real MT, Hutchinson A, Koes B, Laerum E, Malmivaara A, COST B13 Working Group on Guidelines for the Management of Acute Low Back Pain in Primary Care. Chapter 3. European guidelines for the management of acute nonspecific low back pain in primary care. Eur Spine J. 2006;15 Suppl 2:S169-91.

16. Burton AK, Balagué F, Cardon G, Eriksen HR, Henrotin Y, Lahad A, Leclerc A, Müller G, van der Beek AJ, COST B13 Working Group on Gudelines for Prevention in Low Back Pain. Chapter 2. European guidelines for prevention in low back pain. November 2004. Eur Spine J. 2006;15 Suppl 2:S136-68.

17. Chenot JF, Becker A, Leonhardt C, Keller S, Donner-Banzhoff R, Hildebrandt J, et al. Sex differences in presentation, course, and management of low back pain in primary care. Clin J Pain. 2008;24(7):578-84.

18. Leboeuf-Yde C. Body weight and low back pain. A systematic literature review of 56 journal articles reporting on 65 epidemiologic studies. Spine (Phila Pa 1976). 2000;25(2):226-37. Review.

19. Heuch I, Hagen K, Heuch I, Nygaard Ø, Zwart JA. The Impact of body mass index on the prevalence of low back pain. the HUNT Study. Spine (Phila Pa 1976). 2010;35(7):764-8.

20. Seaman DR. Body mass index and musculoskeletal pain: is there a connection? Chiropr Man Therap. 2013;21(15):1-9.

21. Smuck M, Kao MCJ, Brar N, Martinez-Ith A, Choi J, Tomkins-Lane CC. Does physical activity influence the relationship between low back pain and obesity? Spine J. 2014;14:(2):209-16.

22. Harreby M, Hesselsøe G, Kjer J, Neergaard K. Low back pain and physical exercise in leisure time in 38-year-old men and women: a 25-year prospective cohort study of 640 school children. Eur Spine J. 1997;6(3):181-6.

23. Heneweer H, Staes F, Aufdemkampe G, van Rijn M, Vanhees L. Physical activity and low back pain: a systematic review of recent literature. Eur Spine J. 2011;20(6):826-45. Review.

24. Reme SE, Lie SA, Eriksen HR. Are 2 questions enough to screen for depression and anxiety in patients with chronic low back pain? Spine (Phila Pa 1976). 2014;39(7):E455-62.

25. Ferguson S, Allread W, Burr DL, Heaney C, Marras WS. Biomechanical psychosocial and individual risk factors predicting low back functional impairment among furniture distribution employees. Clin Biomech (Bristol, Avon). 2012;27(2):117-23.

26. Bishop A, Foster NE. Do physical therapists in the United kingdom recognize psychosocial factors in patients with acute low back pain? Spine (Phila Pa 1976). 2005;30(11):1316-22.

27. Pengel LH, Herbert RD, Maher CG, Refshauge KM. Acute low back pain: systematic review of its prognosis. BMJ. 2003;327(7410):323. Review.

28. Heymans MW, van Tulder MW, Esmail R, Bombardier C, Koes BW. Back schools for nonspecific low back pain: a systematic review within the framework of the Cochrane Collaboration Back Review Group. Spine (Phila Pa 1976). 2005;30(19):2153-63. Review.

29. Grotle M, Brox JI, Veierød MB, Glomsrød B, Lønn JH, Vøllestad NK. Clinical course and prognostic factors in acute low back pain: patients consulting primary care for the first time. Spine (Phila Pa 1976). 2005;30(8):976-82. 